\title{
Geochemical evidence of denitrification in the Benguela upwelling system
}

\author{
Toby Tyrrell ${ }^{\mathrm{a}, *}$, Michael I. Lucas ${ }^{\mathrm{b}, 1}$ \\ ${ }^{a}$ Southampton Oceanography Centre, School of Ocean and Earth Science, University of Southampton, European Way, \\ Southampton SO14 3ZH, UK \\ ${ }^{\mathrm{b}}$ Zoology Department, University of Cape Town, Rondebosch 7701, South Africa
}

Received 14 December 2000; received in revised form 30 January 2002; accepted 17 May 2002

\begin{abstract}
This paper presents analysis of nitrate, phosphate and silicate data from the Benguela upwelling system. Evidence is presented that suggests denitrification occurring close to shore, and also nutrient trapping. Denitrification leaves an imprint on the water properties in terms of a nitrate deficit, that is to say nitrate concentrations that are significantly less than predicted by multiplying the phosphate concentrations by the Redfield ratio. It is probable that denitrification also causes a decoupling of nitrate and carbon compared to Redfield processes, and large-scale losses of nitrate in the Benguela which are not accompanied by losses of carbon. Nitrate-driven $\mathrm{CO}_{2}$ drawdown following upwelling will be less than it might otherwise be, because of denitrification.

Nutrient trapping (secondary remineralisation) is apparent as enhanced phosphate concentrations, some of which are several $\mu \mathrm{mol}$ higher than in the offshore source waters for upwelling. Waters also become enriched in silicate and to a lesser extent nitrate as they advect across the shelf. By implication the same process should also "supercharge" waters in dissolved inorganic carbon, leading to stronger outgassing of $\mathrm{CO}_{2}$ immediately after upwelling. The effect is again to increase the size of the estimated Benguela upwelling system $\mathrm{CO}_{2}$ source.
\end{abstract}

(C) 2002 Elsevier Science Ltd. All rights reserved.

Keywords: Benguela; Denitrification; Nutrient trapping; Nitrate deficit; Nitrate; Phosphate

\section{Introduction}

\subsection{Ecological competition to extract energy from organic material}

Particulate organic matter (POM), i.e. the collection of living and dead organisms and

\footnotetext{
*Corresponding author. Tel.: +44-23-80-596110; fax: +4423-80-59-30-59.

E-mail address: t.tyrrell@soc.soton.ac.uk (T. Tyrrell).

${ }^{1}$ Present address: Southampton Oceanography Centre, George Deacon Division, European Way, Southampton SO14 3ZH, UK.
}

faecal pellets, is the primary energy and nutrient supply for remineralising bacteria in the sea. This crucial resource is competed for by the different species of bacteria, many of which use different remineralisation reactions. The outcome of the ecological competition depends primarily on which reactions are possible in the local conditions, and then which out of those reactions yields most energy from the decomposition of POM (Canfield, 1993) (Table 1).

When a sufficient concentration of oxygen is present, aerobic bacteria are the most efficient recyclers of organic material (they extract the 
Table 1

Organic matter oxidation pathways, energy yields (taken from Canfield, 1993) and electron acceptor abundances

\begin{tabular}{lll}
\hline Reaction & $\begin{array}{l}\text { Energy yield } \\
\left(\mathrm{kJ} \mathrm{mol}^{-1}\right. \\
\left.\mathrm{of} \mathrm{CH}_{2} \mathrm{O}\right)\end{array}$ & $\begin{array}{l}\text { Abundance of } \\
\mathrm{TEA}^{\mathrm{a}} \\
\left(\mu \mathrm{mol} \mathrm{kg}^{-1}\right)\end{array}$ \\
\hline Oxic respiration & -475 & $\mathrm{O}_{2}: 200$ \\
Denitrification & -448 & $\mathrm{NO}_{3}: 30$ \\
Mn-oxide reduction & -349 & $\mathrm{Mn}: \ll 1$ \\
Fe-oxide reduction & -114 & $\mathrm{Fe}: \ll 1$ \\
Sulphate reduction & -77 & $\mathrm{SO}_{4}: 28,000$ \\
Methane production & -58 & \\
\hline
\end{tabular}

${ }^{\mathrm{a}}$ TEA stands for terminal electron acceptor. Concentrations in the table are approximate averages for deep water.

highest energy yield), and they outcompete those species which use other chemical reactions. If oxygen becomes depleted (hypoxic or anoxic conditions), but nitrate is present, then the next most efficient energy-extractors are the denitrifying bacteria, and they become dominant under these conditions (Knowles, 1982). If the rate of supply of organic matter is sufficient to strip both oxygen and nitrate from the water, then (once rather small quantities of dissolved manganese and iron are also removed) microbes that use the sulphate reduction reaction become dominant. Each remineralising reaction (process) in the sequence requires the use of a particular molecule as a terminal electron acceptor in order for the energy yield to be gained. In the process the concentration of that terminal electron acceptor is depleted. Although a sequence of one reaction after the other is the rule, some overlap can take place. Denitrification and aerobic oxidation, for instance, sometimes take place simultaneously at low oxygen.

This ecological competition takes place in all marine water columns and sediments. In today's ocean it is unusual for oxygen levels to approach zero in the water column, but more common in sediments. Where photosynthetic rates are very high though (e.g. in upwelling systems), the great biological oxygen demand further down in the water column can lead to complete oxygen utilisation. In these conditions a typical sequence is seen: aerobic oxidation $\rightarrow$ denitrification $\rightarrow$ sulphate reduction.

\subsection{The Benguela upwelling system}

Denitrification has been demonstrated in the eastern tropical South Pacific (Codispoti and Christensen, 1985), in a number of upwelling systems (Codispoti, 1983) and is significant in the Peruvian (Codispoti et al., 1986) and Brazilian upwelling system at $23^{\circ} \mathrm{S}$ (Braga and Müller, 1998). It was proposed to be important in the Benguela upwelling system nearly 30 years ago (Calvert and Price, 1971). More recently, Dittmar and Birkicht (2001) have examined N:P ratios within a limited region of the northern Benguela system close to the Angola-Benguela Front and have shown low ratios consistent with denitrification.

Low oxygen events within the Benguela system have been well known for some time (Chapman and Shannon, 1985), although hypoxic $\left(\left[\mathrm{O}_{2}\right]\right.$ $<0.5 \mathrm{ml} \mathrm{l}^{-1}$ ) events within the northern and southern Benguela regions have somewhat differing origins.

\subsubsection{Northern Benguela low oxygen}

The northern boundary of the Benguela system (the Walvis Ridge) is regarded as the "merging zone of the Angola Current and north littoral branch of the Benguela Current" (Moroshkin et al., 1970). Shannon and Nelson (1996) note a poleward undercurrent everywhere south of the Cunene River although Stramma and Peterson (1989) recorded very little mean flow across the Walvis Ridge between the coast and $7^{\circ} \mathrm{E}$.

Nevertheless, off-shelf (200-300 m) poleward flowing water from the Angolan Basin region introduces warm, fresh, low oxygen water into the northern Benguela region, particularly during socalled Benguela Niños (Shannon et al., 1986; Gammelsrød et al., 1998). The most recent event occurred in 1994/95 when severe anoxic conditions $\left(\left[\mathrm{O}_{2}\right]<0.5 \mathrm{ml} \mathrm{l}^{-1}\right)$ prevailed over the shelf in bottom and near-bottom waters from $21-24^{\circ} \mathrm{S}$. These events have a decadal time scale but there are also seasonal intrusions (Boyd et al., 1987). When low oxygen water originating from the Angola Basin is upwelled onto the shelf, it adds to in situ hypoxia originating from the decomposition of organic carbon buried over the shelf. 
Nitrite $\left(\mathrm{NO}_{2}\right)$ is an intermediate in both the denitrification and nitrification processes and has been found in high concentration (up to $10 \mu \mathrm{mol} \mathrm{kg}{ }^{-1}$ ) in the suboxic waters off the coast of Peru where denitrification is intense (Codispoti and Christensen, 1985; Codispoti et al., 1986). Likewise $\mathrm{NO}_{2}$ concentrations of up to $4 \mu \mathrm{mol} \mathrm{kg}{ }^{-1}$ were found over the western Indian shelf in hypoxic water where denitrification also occurred (Naqvi et al., 2000). Dittmar and Birkicht (2001) measured $\mathrm{NO}_{2}$ concentrations up to $0.6 \mu \mathrm{mol} \mathrm{kg} \mathrm{kg}^{-1}$ in the northern Benguela close to the coast.

\subsubsection{Southern Benguela low oxygen}

Within the southern Benguela system, however, oxygen depletion is more of a local event, mainly due to the decay of diatom-dominated blooms but also due to decay of expansive red-tides dominated by the dinoflagellates Ceratium furca and Prorocentrum micans (Pitcher, 1998), all of which contribute to the substantial vertical flux of particulate carbon onto the shelf (Waldron et al., 1992). This large flux of POM onto the shelf, and its remineralisation there, enriches the $\mathrm{NO}_{3}$ concentration of the upwelling water (Bailey, 1987). However, we find (see below) that the amount of enrichment of $\mathrm{NO}_{3}$ is reduced by destruction of $\mathrm{NO}_{3}$ by denitrification in suboxic sediments.

\subsubsection{Benguela sulphate reduction}

In continental margin sediments off central Chile, bacterial dissimilatory sulphate reduction is a commonly observed process (Thamdrup and Canfield, 1996), as it is also in the organically rich shelf sediments ( $\sim 40-75 \mathrm{mg} \mathrm{C}$ org g $^{-1}$ dry weight surface sediment) off the coast of Angola and Namibia (Ferdelman et al., 1999; Fossing et al., 2000). Although nitrate reduction is energetically favoured over sulphate reduction, the latter is by far the most common form of anaerobic decomposition of organic matter, because of the greater availability of sulphate as an electron acceptor in the Benguela surface sediments (Table 1).

Sulphate reduction in the top $0-20 \mathrm{~cm}$ of the sediment attains rates of $2-29 \mathrm{nmol} \mathrm{cm} \mathrm{cm}^{-3} \mathrm{~d}^{-1}$ and is maximal at $2-5 \mathrm{~cm}$ depth, mediated by dense populations of barotolerant giant sulphide oxidis- ing bacteria (Schulz et al., 1999). Highest rates of sulphate reduction were recorded between Walvis Bay $\left(28^{\circ} \mathrm{S}\right)$ and Luderitz $\left(\sim 26.5^{\circ} \mathrm{S}\right)$ along the $1300 \mathrm{~m}$ isobath. This area is characterised by year-round upwelling, high rates of primary production (175-240 $\mathrm{mmol} \mathrm{C} \mathrm{m}^{-2} \mathrm{~d}^{-1}$ ) (Summerhayes et al., 1995), sediments dominated by marine diatomaceous ooze and very little terrigenous input as there is no significant riverine input (Ferdelman et al., 1999). Highest rates of sulphate reduction also tracked the major upwelling centres and were strongly correlated with sediment surface organic carbon concentrations derived from high organic carbon sedimentation rates of $\sim 0.9-1.4 \mathrm{mmol} \mathrm{m}^{-2} \mathrm{~d}^{-1}$ (Wefer and Fischer, 1993). In the same region, Bailey (1991) has measured similar fluxes of organic carbon and has demonstrated the association of this with the development of continental shelf water column anoxia. Ferdelman et al. (1999) argue that sulphate reduction accounts for between $20-96 \%$ of total respiration in the sediments of the Cape Basin at $1300 \mathrm{~m}$ depth.

The high rates of sulphate reduction in this region can be expressed at the surface of the water column as so-called sulphur "events" (e.g. 1997) which it now appears can be detected by satellite remote sensing because of the way the colouring of the water is altered (Weeks et al., 2002). This approach has emphasised that sulphate reduction (and presumably denitrification) is much more widespread than usually detected by ship-board observations.

\subsection{Ecological importance}

The west coast upwelling systems of southern Africa support significant commercially important pelagic, demersal and rock lobster fisheries, which are underpinned by high rates of new production (for review see Hutchings and Field, 1997). Extreme environmental conditions associated with Benguela Niño's (Section 1.2.1) and persistent hypoxic events $\left(\left[\mathrm{O}_{2}\right]<0.5 \mathrm{ml} \mathrm{l}^{-1}\right)$ over the shelf (e.g. in 1994/95) have caused major mortalities to the marine biota. In that year, as in others, there was distributional displacement of Cape hake on the Namibian shelf of the northern Benguela 
(Hamukuaya et al., 1998) as well as catastrophic juvenile Cape hake mortality (Woodhead et al., 1997). In the southern Benguela, there can be equally catastrophic results of local hypoxia and $\mathrm{H}_{2} \mathrm{~S}$ accumulation (e.g. 1997), resulting in mass mortalities of shellfish, rock lobster and even kelps (Pitcher, 1998; Copenhagen, 1953).

\section{Methods}

\subsection{Using nitrate deficits to detect denitrification occurrence}

Nitrate and phosphate concentrations $\left(\left[\mathrm{NO}_{3}\right]\right.$ and $\left.\left[\mathrm{PO}_{4}\right]\right)$ in seawater typically increase and decrease together proportionately, upon descent or ascent through the water column, in the ratio of 15 or 16:1. This is because (Redfield, 1934) the ratio of the two elements $\mathrm{N}$ and $\mathrm{P}$ in POM is likewise $\sim 16: 1$ (Copin-Montegut and CopinMontegut, 1983), and because inorganic $\mathrm{N}$ and $\mathrm{P}$ are released at apparently very similar rates from decaying organic material (Shaffer et al., 1999; Anderson and Sarmiento, 1994; Takahashi et al., 1985; but see also Loh and Bauer, 2000). The strong and linear correlation apparent in scatterplots of $\left[\mathrm{NO}_{3}\right]$ versus $\left[\mathrm{PO}_{4}\right]$ occurs because photosynthesis and remineralisation cause movements up and down a line with slope close to 16:1, but do not cause any significant deviations away from it (Fig. 1). Scatterplots of $\left(\left[\mathrm{NO}_{3}\right]+\left[\mathrm{NH}_{4}\right]+\right.$ $\left[\mathrm{NO}_{2}\right]$ ) versus $\left[\mathrm{PO}_{4}\right]$ would be expected to show even stronger correlation.

Denitrification and nitrogen fixation, on the other hand, do cause deviations away from the $\sim 15: 1$ line. Nitrogen fixation is not a significant process in the Benguela system (Carpenter, 1983) and will therefore be ignored in the rest of this paper. Denitrification has the net effect of removing $\sim 100 \mathrm{~mol}$ of $\mathrm{NO}_{3}$ from the water per $1 \mathrm{~mol}$ addition of $\mathrm{PO}_{4}$ (Codispoti and Christensen, 1985). The N:P ratio of denitrification is therefore about $-100: 1$, in contrast to the $+16: 1$ of aerobic remineralisation (Fig. 1).

It is, therefore, possible (Smith and Hollibaugh, 1998; Gruber and Sarmiento, 1997; Gordon et al., 1996; Smith et al., 1991; possibly first used by

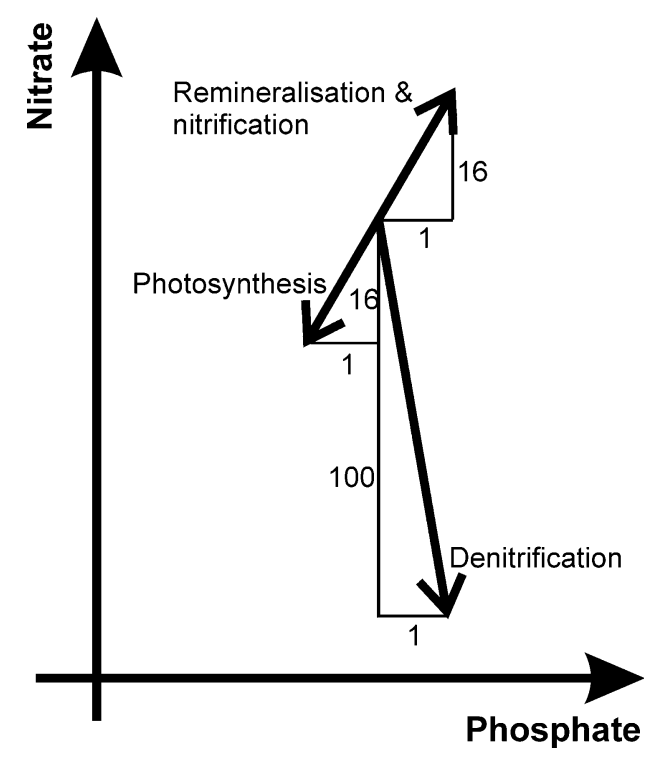

Fig. 1. The impacts of photosynthesis, remineralisation plus nitrification and denitrification on concentrations of nitrate and phosphate (not to scale). Adapted from (Gruber and Sarmiento, 1997).

Cline and Richards, 1972) to calculate a tracer based on nitrate and phosphate - one that is insensitive to photosynthesis and remineralisation processes, but which is sensitive to denitrification and nitrogen fixation. An example of such a tracer is the nitrate deficit $(\Delta N)$ which can be calculated as

$\Delta N=16 *\left[\mathrm{PO}_{4}\right]-\left[\mathrm{NO}_{3}\right]$.

If nitrogen fixation is assumed to be unimportant then any increase in $\Delta N$ above its initial value in deep water offshore is a measure solely of the denitrification history of the water parcel. Another assumption is that the production and remineralisation of dissolved organic $\mathrm{N}$ and $\mathrm{P}$ is either not significant or else also occurs at about a 16:1 ratio (nitrite and ammonium are also omitted because usually only present in small amounts). If these assumptions are reasonable then $\Delta N$ records how much denitrification has taken place in that volume of water. $\Delta N$ calculations are used to calculate rates of nitrogen fixation and denitrification in many coastal locations around the world as part of the LOICZ programme (see http://data. ecology.su.se/MNODE/), but have not yet to our 
knowledge been applied to anywhere in the Benguela upwelling system.

Nitrate deficit is a better indicator of denitrification than $\mathrm{N}: \mathrm{P}$ ratio. Consider for instance deep water with $\left[\mathrm{NO}_{3}\right]=28 \mu \mathrm{mol} \mathrm{kg}$ and $\left[\mathrm{PO}_{4}\right]=$ $2 \mu \mathrm{mol} \mathrm{kg}^{-1}(\mathrm{~N}: \mathrm{P}=14: 1)$ which upwells to the surface. If it then loses $24 \mu \mathrm{mol} \mathrm{kg}-1$ of $\mathrm{NO}_{3}$ and $1.5 \mu \mathrm{mol} \mathrm{kg}$ of $\mathrm{PO}_{4}$ (loss is in $16: 1$ or Redfield proportions) to photosynthesic uptake, then concentrations will decrease to $\left[\mathrm{NO}_{3}\right]=$ $4 \mu \mathrm{mol} \mathrm{kg}{ }^{-1}$ and $\left[\mathrm{PO}_{4}\right]=0.5 \mu \mathrm{mol} \mathrm{kg}{ }^{-1}$. Despite phytoplankton growth being the only process affecting the water since upwelling, the $\mathrm{N}: \mathrm{P}$ ratio decreased from $14: 1$ to an apparently more anomalous $8: 1$. Nitrate deficit, on the other hand, must by definition remain unaltered because of the constant $16: 1$ ratio of uptake or remineralisation.

\subsection{Detecting enrichment by comparison to deep offshore concentrations}

We compare nutrient concentrations in water over the Benguela shelf to concentrations in the source water from which flow onto the shelf is derived. This allows us to determine if water becomes depleted or enriched as it travels onto and across the shelf.

The concentration of nutrients in the source water depends on where the source water is assumed to come from. Calvert and Price (1971) give $150-250 \mathrm{~m}$ as the depth from which upwelled waters are derived, whereas other authors suggest 200-300 m (Section 1.2.1). We calculated nutrient concentrations of source waters by assuming that offshore (greater than $160 \mathrm{~km}$ from the shore) water between 150 and $300 \mathrm{~m}$ depth is the source of water advected onto the shelf. We then examined our dataset (see below) for samples taken from bottles fired between 150 and $300 \mathrm{~m}$ during offshore casts. Nutrient concentrations measured in those bottles were:

$\left[\mathrm{NO}_{3}\right]$ : average $=15 \mu \mathrm{mol} \mathrm{kg}{ }^{-1}$, range $=5-30 \mu \mathrm{mol} \mathrm{kg}{ }^{-1}$.

$\left[\mathrm{PO}_{4}\right]$ : average $=1.5 \mu \mathrm{mol} \mathrm{kg}{ }^{-1}$, range $=0.5-3.0 \mu \mathrm{mol} \mathrm{kg}{ }^{-1}$.

$\left[\mathrm{SiO}_{4}\right]$ : average $=11 \mu \mathrm{mol} \mathrm{kg}{ }^{-1}$, range $=2-17 \mu \mathrm{mol} \mathrm{kg} \mathrm{kg}^{-1}$.

\section{Data and results}

Nutrient data collected by Geoff Bailey (SFRI) and others were obtained from the South African Data Centre for Oceanography (SADCO) archive and analysed. We did not perform any quality control or screening of this data, other than to exclude data collected before 1970. Data from more than 1000 casts from the period 1973-1993 and the area $\left(12-17^{\circ} \mathrm{E}, 20-32^{\circ} \mathrm{S}\right)$ (Fig. 2) were used. Anticipating strong denitrification associated with the low oxygen waters of many parts of the Benguela system, we analysed the data for nitrate deficits.

\subsection{Scatterplots}

As a first step, we grouped all of the data, irrespective of season, year, depth or location into a scatterplot of $\left[\mathrm{NO}_{3}\right]$ versus $\left[\mathrm{PO}_{4}\right]$ (Fig. 3a). A least absolute deviation best-fit line (Press et al., 1992) to all of the data produces $\left[\mathrm{NO}_{3}\right]=$ $9.0 *\left[\mathrm{PO}_{4}\right]-1.0$. This is substantially different from the $\left[\mathrm{NO}_{3}\right]=14.1 *\left[\mathrm{PO}_{4}\right]-1.53$ of the main trend in the World Ocean Atlas '94 global data set (NODC, 1994) used by Tyrrell and Law (1997), but the global best-fit line was obtained by excluding LNP points (where LNP = low nitrate:phosphate, such that $\left(\mathrm{NO}_{3} / \mathrm{PO}_{4}\right)<3.0$ and $\mathrm{PO}_{4}>$ $1.5 \mu \mathrm{mol} \mathrm{kg}{ }^{-1}$; shaded area in Fig. 3a). When only the main trends of both datasets are considered, the Benguela dataset is similar to the global dataset.

There are many LNP points (7\% of the total) in this data, and these are separate from the cluster of LNP points reported by Tyrrell and Law (1997) from the Agulhas Retroflection area, which were later found to be incorrect (Tyrrell and Law, 1998).

Does the Fig. 3a scatterplot as a whole provide evidence of denitrification? The low slope of the best-line fit to all the data is general evidence of denitrification. In addition, there is a clear asymmetry in the scatter of points, with a much greater number of points below and to the right of the main trend than above and to the left of it. This indicates that a non-random process is either removing $\mathrm{N}$ without simultaneously removing $\mathrm{P}$, 


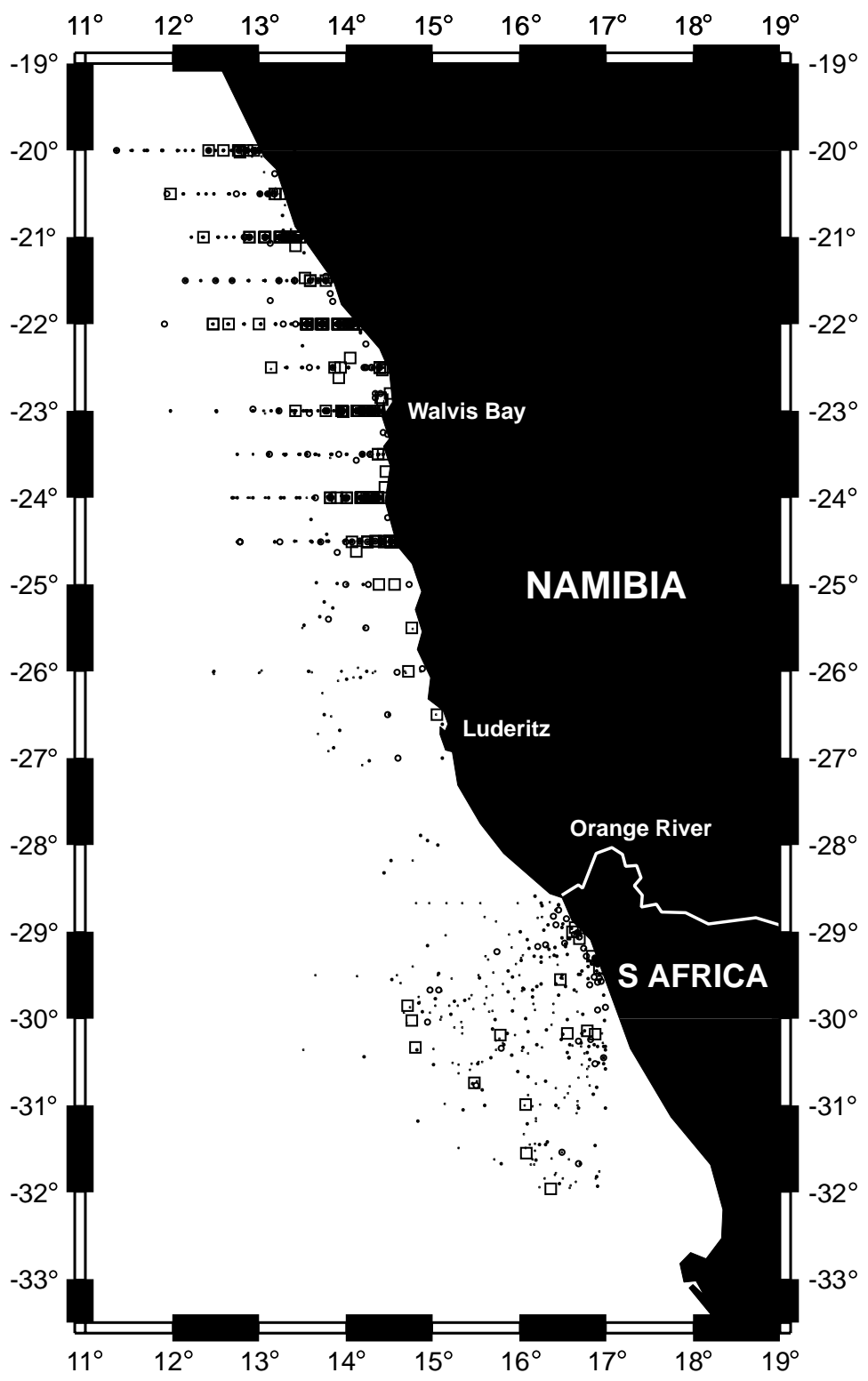

Fig. 2. Data locations: each symbol shows the position of one cast during which nutrient concentrations were measured from one or

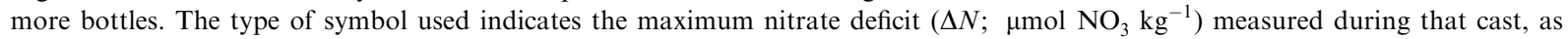
follows: (.), $\Delta N<10 ;(\bullet), 10<\Delta N<20 ;(\circ), 20<\Delta N<30 ;(\square), \Delta N>30$.

or else adding $\mathrm{P}$ without simultaneously adding $\mathrm{N}$. We suggest this process is denitrification. LNP points are found in other high-productivity coastal areas in which denitrification is known to occur (Tyrrell and Law, 1998; Naqvi et al., 2000;
Codispoti, 1989). However, the lack of a large number of points where both $\left(\left[\mathrm{NO}_{3}\right] \simeq 0.0\right)$ and $\left(\left[\mathrm{PO}_{4}\right]\right.$ significantly greater than 0.0$)$, is evidence against denitrification proceeding to nitrate exhaustion throughout the area. The observations of 

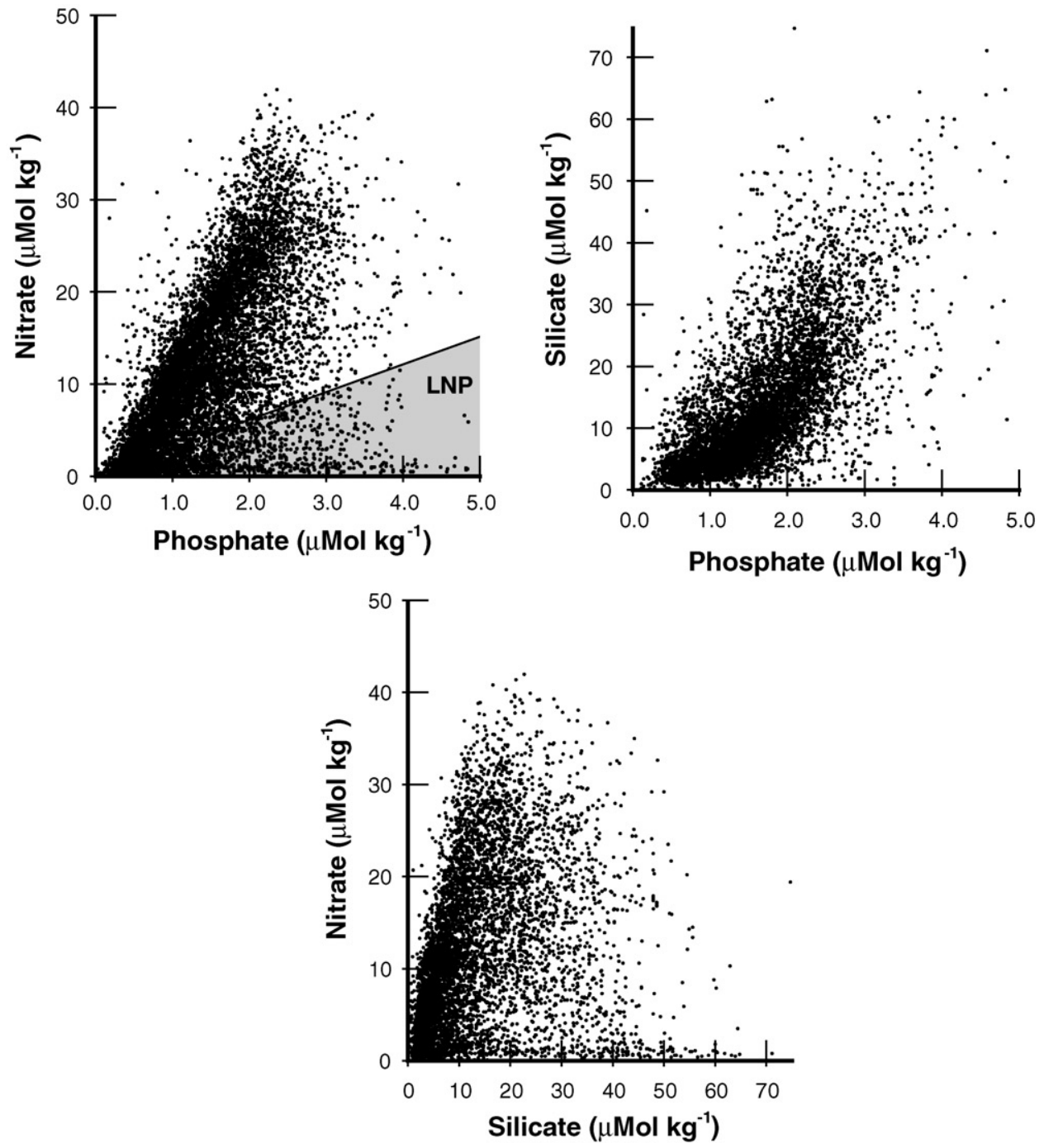

Fig. 3. Scatterplots of: (a) $\left[\mathrm{NO}_{3}\right]$ versus $\left[\mathrm{PO}_{4}\right]$, (b) $\left[\mathrm{SiO}_{4}\right]$ versus $\left[\mathrm{PO}_{4}\right]$, and (c) $\left[\mathrm{NO}_{3}\right]$ versus $\left[\mathrm{SiO}_{4}\right]$ (all $\mu \mathrm{mol} \mathrm{kg}^{-1}$ ). The shaded area in (a) shows the subset of the data designated as low N:P (LNP, see text).

sulphide production events (Pitcher, 1998) show that such strong denitrification must occur in some locations at some times though.

It is possible to get some idea of whether it is perturbations to nitrate or perturbations to phosphate that are causing the anomalous points away from the main trend. This is done by comparing scatterplots of silicate versus phosphate (Fig. 3b; same as Fig. 3a except nitrate is replaced by silicate), and nitrate versus silicate (Fig. 3c; same as Fig. 3a except phosphate is replaced by silicate). The result of this comparison is not wholly conclusive, in that anomalous points away from the main trend (to the right and beneath it) are found in both plots. However, many more occur in Fig. 3c, suggesting that it is mainly perturbations to nitrate that are responsible. Of course if both phosphate and silicate are 
preferentially released from particles (compared to nitrate) by dissolution under severely hypoxic conditions, then this too could account for the observed patterns, but the more parsimonious explanation (denitrification) is assumed here.

\subsection{Plot of nitrate deficit versus temperature}

As a second step, we plotted $\Delta N$ versus temperature in our data set (Fig. 4). This plot reveals that maximum nitrate deficits are large, $40 \mu \mathrm{mol} \mathrm{NO}_{3} \mathrm{~kg}^{-1}$ or more. Large nitrate deficits seems to be correlated with water temperatures of $12-13^{\circ} \mathrm{C}$, for reasons we do not understand. There are many more points above the main cluster than below it; that is to say there are more positive than negative nitrate deficits, as one would expect if the positive nitrate deficits are due to denitrification rather than to random measurement error.

\subsection{Plot of nitrate versus temperature}

Next we plotted $\left[\mathrm{NO}_{3}\right]$ versus temperature in our data set, with the symbol used depending on the nitrate deficit for that bottle (Fig. 5a). In an

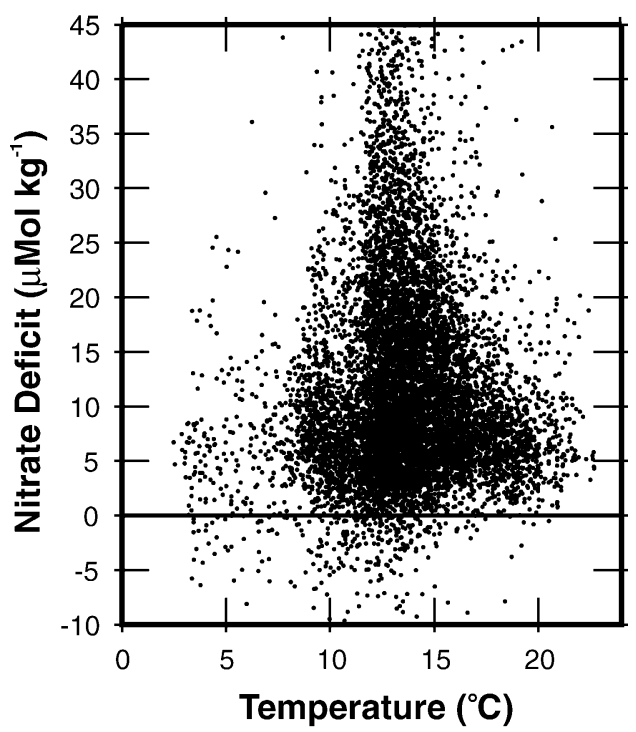

Fig. 4. Nitrate deficit $\left(\Delta N, \quad \mu \mathrm{mol} \mathrm{NO} \mathrm{NO}_{3} \mathrm{~kg}^{-1}\right)$ versus temperature $\left({ }^{\circ} \mathrm{C}\right)$. upwelling system nitrate and temperature should be correlated due to biological removal of nitrate occurring concurrently with heating of the initially cold upwelled water (Dugdale et al., 1989; Voituriez and Herbland, 1984), and this is generally apparent in Fig. 5a. The initial expectation was that points with high nitrate deficit (which have experienced significant denitrification) should have lower than normal nitrate and hence should be below the average trend in the $\mathrm{NO}_{3}$ versus temperature plot. While this is most usually the case, there are also a number of points with high nitrate deficit on the "wrong" side of the average trend.

\subsection{Plot of phosphate versus temperature}

The plot of $\left[\mathrm{PO}_{4}\right]$ versus temperature, however, shows a more defined pattern (Fig. 5b). There is a similar trend between temperature and phosphate because phosphate is also taken up by phytoplankton as upwelled water heats up at the surface. The higher the nitrate deficit, the higher above the main phosphate-temperature trend the points tend to lie. When compared to the nitrate-temperature plot (Fig. 5a), the points with large nitrate deficit are less randomly positioned compared to the main trend.

\subsection{Plot of silicate (silicic acid) versus temperature}

The plot of $\left[\mathrm{SiO}_{4}\right]$ versus temperature (Fig. 5c) also shows a more defined pattern than Fig. $5 \mathrm{a}$. Silicate is taken up into diatoms, usually the dominant phytoplankton in upwelling systems, into their tests (shells), which then sink out along with the diatom organic matter. For this reason there is a similar trend between temperature and silicate. The highest silicate values are all from bottles with high nitrate deficits. This is perhaps to be expected (both being associated with intense remineralisation), and is evidence that the main patterns in the data are not solely due to random noise in measurements. Silicate is an independent measurement, because nitrate deficit is calculated from nitrate and phosphate. 

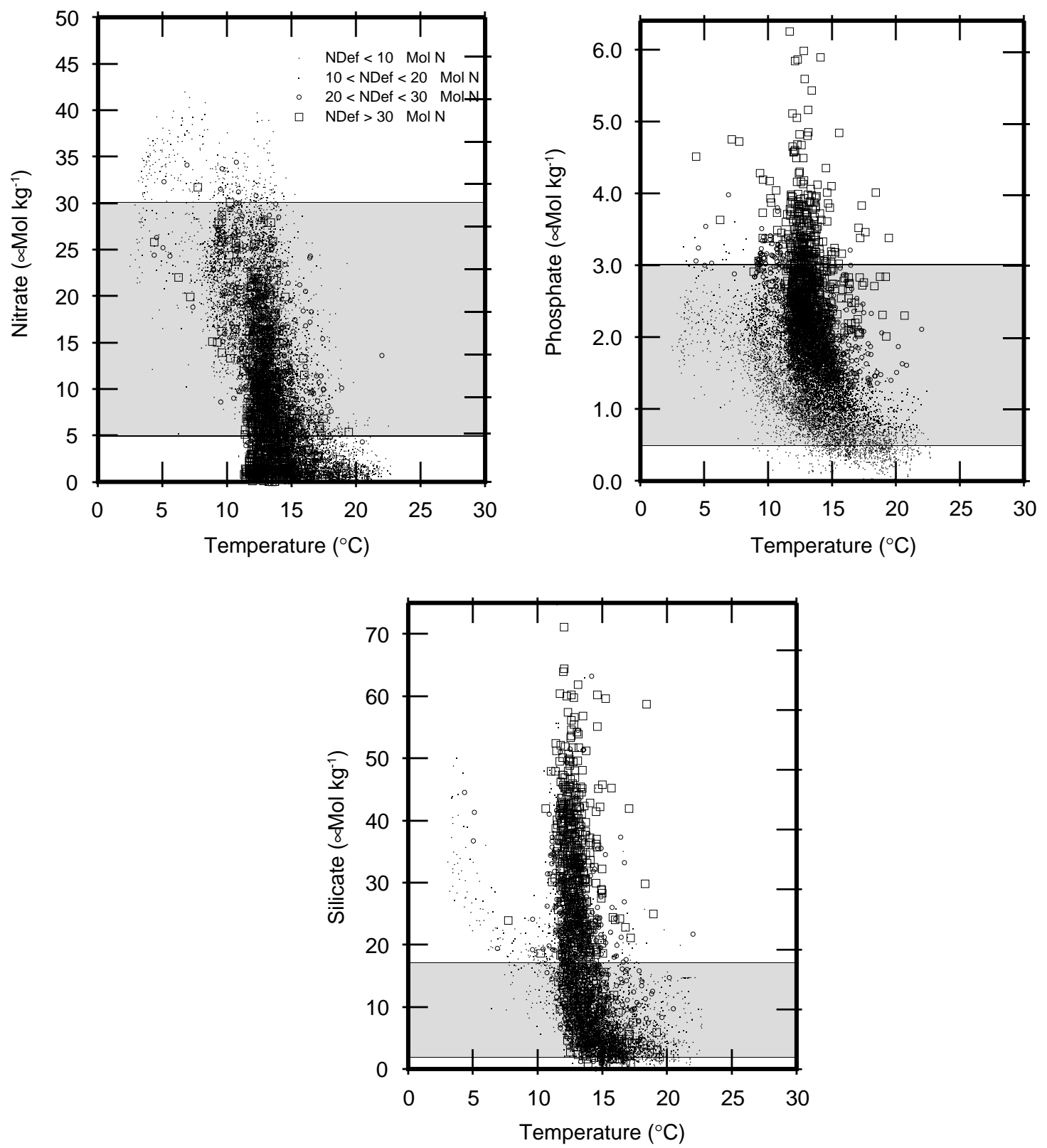

Fig. 5. (a) Nitrate, (b) phosphate and (c) silicate (all $\mu \mathrm{mol} \mathrm{kg}{ }^{-1}$ ) versus temperature $\left({ }^{\circ} \mathrm{C}\right.$ ); with symbols indicating nitrate deficit as shown in the legend in (a). The shaded area in each plot indicates the range of concentrations of that nutrient found in source waters offshore (150-300 m depth, see Section 2.2).

\subsection{Plots of nitrate deficit, nitrate and phosphate versus distance from the coast}

Finally, we also plotted $\left[\mathrm{NO}_{3}\right],\left[\mathrm{PO}_{4}\right]$ and $[\Delta N]$ versus approximate distance from the coast
(Fig. 6). The points come from all depths on each cast. An increase in $\Delta N$ with proximity to shore is apparent in this data. Average $\Delta N$ increases near to the shore, as does the fraction of high $\Delta N$ values. Phosphate 

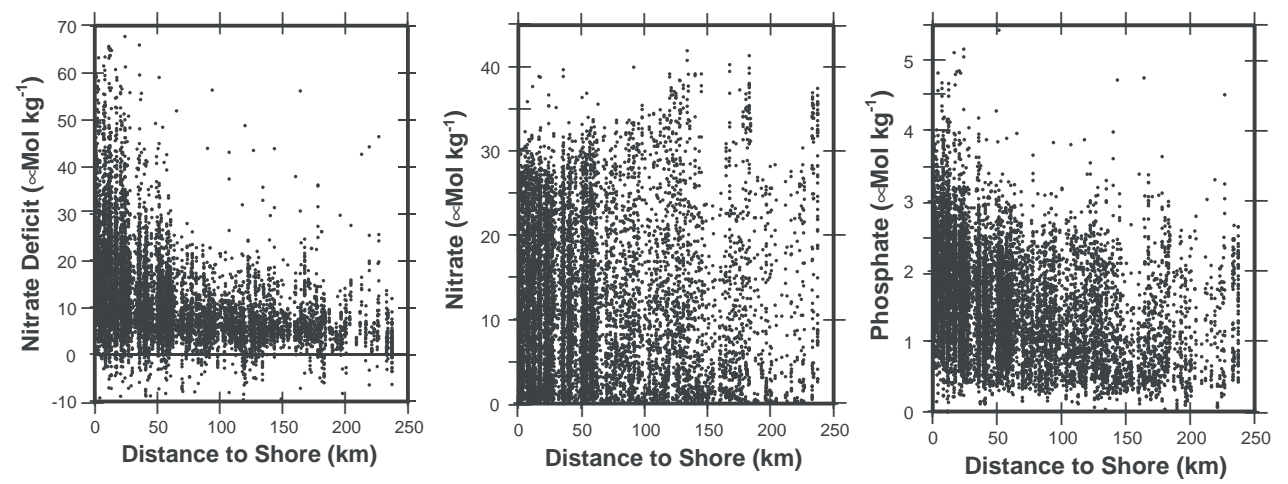

Fig. 6. (a) Nitrate deficit, (b) nitrate, and (c) phosphate (all $\mu \mathrm{mol} \mathrm{kg}^{-1}$ ) versus distance to the coast (km).

concentrations are also on average higher near to shore.

\section{Discussion}

\subsection{What do the data tell us?}

River inputs are unlikely to be responsible for the patterns seen here. River water on average (but by no means always) has a high molar N:P ratio (average 30:1) (Berner and Berner, 1996), but in any case there are few rivers of any size draining into the ocean along this part of the African coast, with the Orange River being one exception. The mouth of the Orange River enters the ocean at $28.6^{\circ} \mathrm{S}$.

We suggest that a more likely explanation for the patterns in the $\mathrm{NO}_{3}$ and $\mathrm{PO}_{4}$ data is a combination of nutrient trapping and denitrification. The possibility of nutrient trapping is shown in a schematic diagram in Fig. 7. Dittmar and Birkicht (2001) refer to this phenomenon by an alternative name, "secondary remineralisation". Cold, dense, nutrient-rich deep water from offshore can become yet further enriched in nutrients as it travels over the continental shelf sediments before upwelling to the surface. This can occur if organic particles sink into it from above, fuelled by nutrients extracted from previously upwelled surface water advecting back offshore (Fig. 7). Upwards diffusion of nutrients out of sediment pore waters will also enrich currents travelling over the sediments.

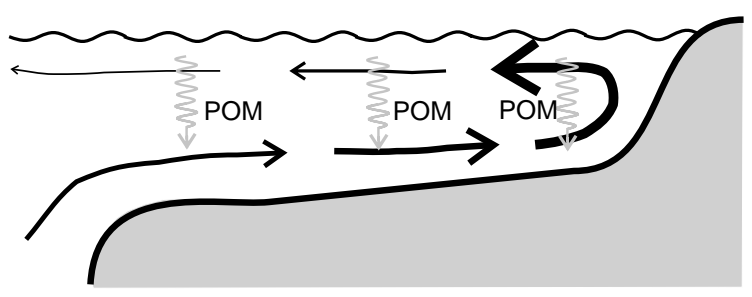

Fig. 7. Schematic of proposed nutrient-trapping mechanism: deep nutrient-rich water from off-shore acquires yet more nutrients as it passes over the shelf sediments, before it finally upwells closer to shore. The remineralisation in the sediments and/or the water column is of POM sinking from the surface, the POM creation there fuelled by nutrients stripped from the surface water advecting back off-shore. The thickness of the arrow represents nutrient concentration.

Nutrient trapping explains the very high phosphate concentrations shown in Fig. 5b, and denitrification explains the lack of equivalently high nitrate concentrations in Fig. 5a. Fig. 8 depicts how nutrient trapping and denitrification are envisaged to affect the two plots in Fig. 5. Bailey and Chapman $(1985,1991)$ found increased nutrients in water upwelling inshore (in St Helena Bay) relative to that in offshore source waters and attributed the increase to nutrients released by the organic-rich sediments. Calvert and Price (1971) came to similar conclusions to ourselves (denitrification and nutrient trapping), but based on only 20 stations carried out during October 1968. We support their findings using new analysis techniques (e.g. nitrate deficits) and with a dataset more than 50 times larger. Our only modification 

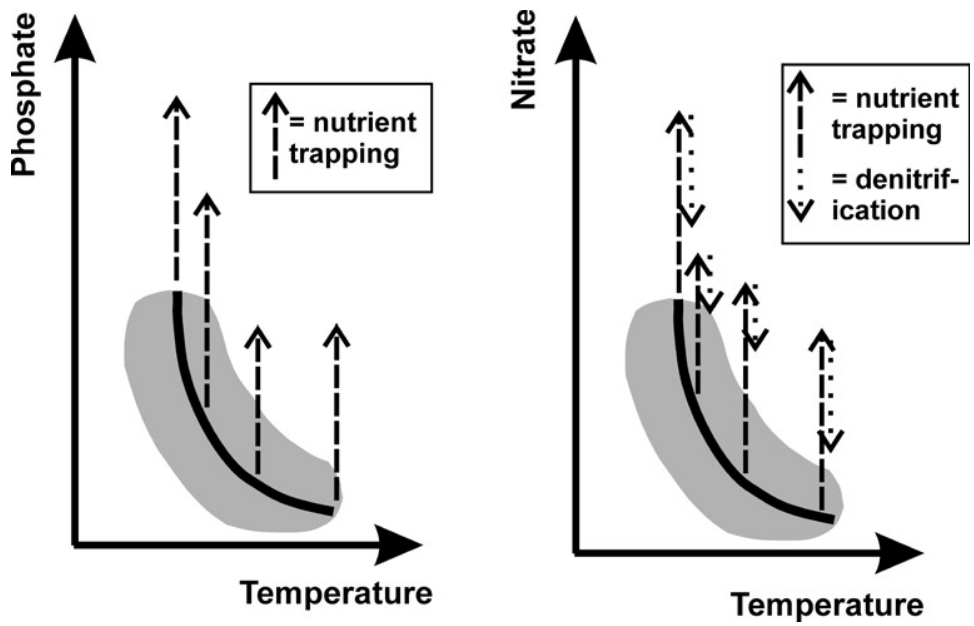

Fig. 8. Schematic showing how otherwise simple trends between nutrient concentration and temperature may be altered by nutrient trapping and, in the case of nitrate, by denitrification.

to their conclusions is that we find abundant evidence of phosphate enrichment due to nutrient trapping whereas they found none.

Dittmar and Birkicht (2001) observed highest phosphate and silicate surface concentrations in the same place as a local minimum in nitrate. They attributed this to a bloom of non-siliceous phytoplankton, but we think a more likely explanation is high organic matter flux to sediments causing both strong local enrichment in $\left[\mathrm{PO}_{4}\right]$ and $\left[\mathrm{SiO}_{4}\right]$ and also intense local denitrification due to oxygen depletion.

\subsection{Biogeochemical implications}

Comparing Figs. 5a and $\mathrm{b}$ it is apparent that phosphate concentrations on the shelf become enriched more than nitrate concentrations, compared to original (source water) concentrations. We agree with Dittmar and Birkicht (2001) and Bailey and Chapman (1991) that phosphate does not as a rule fall to near-zero values either in aged or recently upwelled waters, and for that reason does not limit primary production in the Benguela. There are, by contrast, many near-zero nitrate values (Fig. 5a).

While above-shelf waters also become enriched in nitrate, the enrichment is not so great because of denitrification. We agree with Dittmar and
Birkicht (2001) that there is evidence for "considerable nitrogen losses off Namibia", but not that "nitrate was not regenerated".

From a biogeochemical perspective, denitrification will clearly reduce the $\mathrm{NO}_{3}$ flux into surface waters. This $\mathrm{NO}_{3}$ flux has been used by Waldron and Probyn (1992) to calculate potential new production in the Benguela system and, from that, to calculate a carbon budget (Waldron et al., 1992, 1998). Their lack of consideration of denitrification (denitrification is not included in their schematic of probable $\mathrm{NO}_{3}-\mathrm{N}$ pathways in the Benguela (Fig. 3, Waldron et al., 1992)) will not, however, have led them to underestimate new production or the carbon source strength, as has been argued by Dittmar and Birkicht (2001). This is because Waldron and Probyn's calculations are based on observed nitrate concentrations in the surface layer, and hence automatically take into account the effect denitrification has already had on these concentrations before the water reached the surface.

Nevertheless, there are important implications for the net ocean-atmosphere exchange of $\mathrm{CO}_{2}$ based on the stoichiometric (un)coupling of $\left[\mathrm{TCO}_{2}\right]$ and $\left[\mathrm{NO}_{3}\right]$ during upwelling. The $\left[\mathrm{TCO}_{2}\right]:\left[\mathrm{NO}_{3}\right]$ ratio presumably increases as the water flows over the shelf, acquiring $\mathrm{TCO}_{2}$ as it does $\mathrm{PO}_{4}$, but not simultaneously acquiring $\mathrm{NO}_{3}$ 
(or acquiring less of it). Remineralisation dynamics of carbon are fairly similar to those of phosphorus, although carbon is released slightly more slowly from organic matter (Anderson and Sarmiento, 1994; Shaffer et al., 1999). If the data were available to construct a plot similar to Figs. 5a-c, but for $\left[\mathrm{TCO}_{2}\right]$, a similar plot to Fig. $5 \mathrm{~b}$ would be expected, at least as regards the degree of enrichment above offshore deep water at the time when the upwelled water first hits the surface. After that time degassing of carbon dioxide but not phosphorus will tend to make the plots less similar.

If our analysis is correct then when upwelling water reaches the surface in the Benguela it must be "supercharged" with $\mathrm{CO}_{2}$. That is to say $\left[\mathrm{TCO}_{2}\right]$ is even higher than in the offshore source waters before they advect onshore and then upwell. Strong outgassing is therefore to be expected. A simple Redfield ratio-based calculation predicts that the amount of supercharging of $\left[\mathrm{TCO}_{2}\right]$ will on occasion be as high as $200 \mu \mathrm{mol} \mathrm{kg}{ }^{-1}$, obtained by multiplying $\left[\mathrm{PO}_{4}\right]$ supercharging of up to $2 \mu \mathrm{mol} \mathrm{kg}{ }^{-1}$ (Fig. 5b) by the Redfield ratio of organic matter of $\mathrm{C}: \mathrm{P}=$ 106:1 (Redfield, 1934). A dissolved inorganic carbon system model (Lewis and Wallace, 1997) predicts that this should result in upwelled waters in which $p \mathrm{CO}_{2}$ (aq) (the partial pressure of $\mathrm{CO}_{2}$ in water) is supercharged by several hundred ppm over the normal (upwelling without enrichment) case.

This strong $\mathrm{CO}_{2}$ outgassing during the initial active phase of upwelling will not be matched by subsequent $\mathrm{NO}_{3}$-driven $\mathrm{CO}_{2}$ draw-down as long as phytoplankton primary production is created in Redfield elemental proportions and is not itself uncoupled. When $\left[\mathrm{NO}_{3}\right]$ has been exhausted, $\left[\mathrm{TCO}_{2}\right]$ will still be higher than in adjacent offshore nutrient-poor surface waters, because of the simultaneous enrichment in $\mathrm{TCO}_{2}$ and partial removal of $\mathrm{NO}_{3}$ by denitrification from the waters before they were upwelled.

\subsection{Recommendations for future work}

A testable prediction of this study is that $\mathrm{TCO}_{2}$ concentrations in newly upwelled water near to the coast should be up to $200 \mu \mathrm{mol} \mathrm{kg}{ }^{-1}$ higher than in the offshore source waters for upwelling. This prediction should hold true over parts of the shelf which have suboxic sediments or a suboxic water column. The partial pressure of carbon dioxide $\left(p \mathrm{CO}_{2}\right)$ should likewise be elevated above that expected purely from bringing offshore deep water straight to the surface without alteration.

Further nutrient measurements in the system, in particular along transects perpendicular to the coast and through suboxic waters, can test the hypotheses presented here. Direct assays of denitrification (e.g. Devol, 1991) in Benguela sediments would confirm or contest our interpretation as to the quantitative significance of denitrification in this system.

A combined numerical model of the system (for instance see Monteiro, 1996 for a previous study), including physics (currents), phytoplankton growth and decay, nutrient cycling, carbon cycling, and sediment processes is required to gain a full understanding of how the Benguela system functions as a biogeochemical whole.

\section{Conclusions}

The denitrification process leaves a geochemical fingerprint in the form of a nitrate deficit in the waters of the Benguela. Our analysis of multiannual nutrient data from the Benguela system shows nitrate deficits of up to $40 \mu \mathrm{mol} \mathrm{NO}_{3} \mathrm{~kg}^{-1}$, with greater nitrate deficits close to the coast. Large amounts of nitrate are continuously being removed from the system by denitrification, thus preventing some of the "fuel" for primary production from reaching the surface.

There is also evidence of nutrient trapping leading to higher nutrient concentrations than found offshore in deep water. This holds for phosphate and silicate but not to the same extent for nitrate, because of denitrification. By implication it should also hold for dissolved inorganic carbon, but data are needed in order to test this claim.

\section{Acknowledgements}

We are grateful to Geoff Bailey at MCM, Cape Town for permission to use his data, and also for 
permission from the Republic of Namibia Ministry of Fisheries and Marine Resources to use data collected in Namibian waters. We thank Ursula von St Ange and Marten Grundlingh (SADCO) for making the data available to us, and Howard Waldron, Pedro Monteiro, Geoff Bailey, Steve Smith and an anonymous reviewer for helpful comments and advice. This work was partly funded by a UK Natural Environment Research Council fellowship (GT5/98/15/MSTB) to TT.

\section{References}

Anderson, L.A., Sarmiento, J.L., 1994. Redfield ratios of remineralization determined by nutrient data-analysis. Global Biogeochemical Cycles 8, 65-80.

Bailey, G.W., 1987. The role of regeneration from the sediments in the supply of nutrients to the euphotic zone in the southern Benguela system. South African Journal of Marine Science 5, 273-285.

Bailey, G.W., 1991. Organic carbon flux and development of oxygen deficiency on the modern Benguela continental shelf south of $22^{\circ} \mathrm{S}$ : spatial and temporal variability. In: Tyson, R.V., Pearson, T.H. (Eds.), Modern and Ancient Continental Shelf Anoxia, Vol. 58. Geological Society Special Publication, London, UK, pp. 171-183.

Bailey, G.W., Chapman, P., 1985. The nutrient status of the St Helena Bay region in February 1979. In: Shannon, L.V. (Ed.), South African Ocean Colour and Upwelling Experiment. Sea Fisheries Research Institute, Cape Town, pp. $125-145$

Bailey, G.W., Chapman, P., 1991. Short-term variability during an anchor station study in the southern Benguela upwelling system: chemical and physical oceanography. Progress in Oceanography 28, 9-37.

Berner, E.K., Berner, R.A., 1996. Global Environment: Water, Air, and Geochemical Cycles. Prentice-Hall, Englewood Cliffs, NJ, USA.

Boyd, A.J., Salat, J., Maso, M., 1987. The seasonal intrusion of relatively saline water on the shelf off northern and central Namibia. In: Payne, A.I.L., Gulland, J.A., Brink, K.H. (Eds.), The Benguela and Comparable Ecosystems. South African Journal of Marine Science 5, 107-120.

Braga, E.S., Müller, T.J., 1998. Observation of regeneration of nitrate, phosphate and silicate during upwelling off Ubatuba, Brazil, $23^{\circ} \mathrm{S}$. Continental Shelf Research 18, 915-922.

Calvert, S.E., Price, N.B., 1971. Upwelling and nutrient regeneration in the Benguela current, October, 1968. Deep-Sea Research 18, 505-523.

Canfield, D.E., 1993. Organic matter oxidation in marine sediments. In: Wollast, R., Mackenzie, F.T., Chou, L. (Eds.), Interactions of C, N, P and S Biogeochemical Cycles and Global Change, NATO ASI Series, Vol. 14. Springer, Berlin, pp. 1-61.

Carpenter, E.J., 1983. Nitrogen fixation by marine Oscillatoria (Trichodesmium) in the world's oceans. In: Carpenter, E.J., Capone, D.G. (Eds.), Nitrogen in the Marine Environment. Academic Press, New York.

Chapman, P., Shannon, L.V., 1985. The Benguela ecosystem. 2. Chemistry and related processes. Oceanography and Marine Biology Annual Review 23, 183-251.

Cline, J.D., Richards, F.A., 1972. Oxygen deficient conditions and nitrate reduction in the eastern tropical North Pacific Ocean. Limnology and Oceanography 17, 885-900.

Codispoti, L.A., 1989. Phosphorus versus nitrogen limitation of new and export production. In: Berger, W.H., Smetacek, V.S., Wefer, G. (Eds.), Productivity of the Ocean: Present and Past. Academic Press, New York, pp. 377-394.

Codispoti, L.A., 1983. Nitrogen in upwelling systems. In: Carpenter, E.J., Capone, D.G. (Eds.), Nitrogen in the Marine Environment. Academic Press, New York, pp. 513-564.

Codispoti, L.A., Christensen, J.P., 1985. Nitrification, denitrification and nitrous oxide cycling in the eastern tropical South Pacific Ocean. Marine Chemistry 16, 277-300.

Codispoti, L.A., Friederich, G.E., Packard, T.T., Glover, H.E., Kelly, P.J., Spinrad, R.W., Barber, R.T., Elkins, J.W., Ward, B.B., lipschultz, F., Lostaunau, N., 1986. High nitrite levels off northern Peru: a signal of instability in the marine denitrification rate. Science 233, 1200-1202.

Copenhagen, W.J., 1953. The periodic mortality of fish in the Walvis Bay region: a phenomenon within the Benguela current. Investigational Report, Division Fisheries Union of South Africa 14, 1-35.

Copin-Montegut, C., Copin-Montegut, G., 1983. Stoichiometry of carbon, nitrogen, and phosphorus in marine particulate matter. Deep-Sea Research 30 (1), 31-46.

Devol, A.H., 1991. Direct measurement of nitrogen gas fluxes from continental shelf sediments. Nature 349, 319-321.

Dittmar, T., Birkicht, M., 2001. Regeneration of nutrients in the northern Benguela upwelling and the Angola-Benguela Front areas. South African. Journal of Science 97, 239-246.

Dugdale, R.C., Morel, A., Bricaud, A., Wilkerson, F.P., 1989. Modeling new production in upwelling centers - a casestudy of modeling new production from remotely sensed temperature and color. Journal of Geophysical Research 94 (C12), 18 119-18 132.

Ferdelman, T.G., Fossing, H., Neumann, K., Schulz, H.D., 1999. Sulfate reduction in surface sediments of the southeast Atlantic continental margin between $15^{\circ} 38^{\prime} \mathrm{S}$ and $27^{\circ} 57^{\prime} \mathrm{S}$ (Angola and Namibia). Limnology and Oceanography 44 (3), 650-661.

Fossing, H., Ferdelman, T.G., Berg, P., 2000. Sulfate reduction and methane oxidation in continental margin sediments influenced by irrigation (South-East Atlantic off Namibia). Geochimica et Cosmochimica Acta 64 (5), 897-910.

Gammelsrød, T., Bartholomae, C.H., Boyer, D.C., Filipe, V.L.L., O'Toole, M.J., 1998. Intrusions of warm surface 
water along the Angolan-Namibian coast in FebruaryMarch 1995: the 1995 Benguela Niño. In: Pillar, S.C., Moloney, C.L., Payne, A.I.L., Shillington, F.A. (Eds.), Benguela Dynamics: Impacts of Variability on Shelf-Sea Environments and their Living Resources, South African Journal of Marine Science 19, 41-56.

Gordon Jr., D.C., Boudreau, P.R., Mann, K.H., Ong, J.-E., Silvert, W.L., Smith, S.V., Wattayakorn, G., Wulff, F., Yanagi, T., 1996. LOICZ Biogeochemical Modelling Guidelines. LOICZ Reports \& Studies No. 5, 1-96.

Gruber, N., Sarmiento, J.L., 1997. Global patterns of marine nitrogen fixation and denitrification. Global Biogeochemical Cycles 11, 235-266.

Hamukuaya, H., O’Toole, M.J., Woodhead, P.M.J., 1998. Observations of severe hypoxia and offshore displacement of Cape hake over the Namibian shelf in 1994. In: Pillar, S.C., Moloney, C.L., Payne, A.I.L., Shillington, F.A. (Eds.), Benguela Dynamics: Impacts of Variability on Shelf-Sea Environments and their Living Resources. South African Journal of Marine Science 19, 57-59.

Hutchings, L., Field, J.G., 1997. Biological oceanography in South Africa, 1896-1996: observations, mechanisms, monitoring and modelling. Transactions of the Royal Society of South Africa 52 (1), 81-120.

Knowles, R., 1982. Denitrification. Microbiological Reviews 46 (1), 43-70.

Lewis, E., Wallace, D., 1997. Documentation of program CO2SYS. Inorganic Carbon for the World Ocean Circulation Experiment - World Hydrographic Program, US Department of Energy Office of Health and Environmental Research.

Loh, A.N., Bauer, J.E., 2000. Distribution, partitioning and fluxes of dissolved and particulate $\mathrm{C}, \mathrm{N}$ and $\mathrm{P}$ in the eastern North Pacific and Southern Oceans. Deep-Sea Research 47, 2287-2316.

Monteiro, P.M.S., 1996. The oceanography, biogeochemistry and fluxes of $\mathrm{CO}_{2}$ in the Benguela upwellng system: a box model approach. Ph.D. Thesis, University of Cape Town, South Africa.

Moroshkin, K.V., Bubnov, V.A., Bulatov, R.V., 1970. Water circulation in the southeastern Atlantic. Oceanology 10 (1), 27-34.

Naqvi, S.W.A., Jayakumar, D.A., Narvekar, P.V., Naik, H., Sarma, V.V.S.S., D'Souza, W., Joseph, S., George, M.D., 2000. Increased marine production of $\mathrm{N}_{2} \mathrm{O}$ due to intensifying anoxia on the Indian continental shelf. Nature 408, 346-349.

NODC World Ocean Atlas, 1994. Data set (http://www.nodc.noaa.gov/OC5/pr_woa4.html).

Pitcher, G.C., 1998. Harmful algal blooms of the Benguela current. MCM/IOC Report, National Book Printers, Cape Town, South Africa, pp. 1-20.

Press, W.H., Teukolsky, S.A., Vetterling, W.T., Flannery, B.P., 1992. Numerical Recipes in FORTRAN, 2nd Edition. Cambridge University Press, Cambridge.

Redfield, A.C., 1934. On the proportions of organic derivatives in sea water and their relation to the composition of plankton. In: James Johnston Memorial Volume. University Press of Liverpool, Liverpool, UK, pp. 176-192.

Schulz, H.N., Brinkhoff, T., Ferdelman, T.G., Hernández Mariné, M., Teske, A., Jørgensen, B.B., 1999. Dense populations of a giant sulfur bacterium in Namibian Shelf sediments. Science 284, 493-495.

Shaffer, G., Bendtsen, J., Ulloa, O., 1999. Fractionation during remineralization of organic matter in the ocean. Deep-Sea Research I 46, 185-204.

Shannon, L.V., Boyd, A.J., Brundrit, G.B., Tauntonclark, J., 1986. On the existence of an El-Niño-type phenomenon in the Benguela system. Journal of Marine Research 44, 495-520.

Shannon, L.V., Nelson, G., 1996. The Benguela: large scale features and processes and system variability. In: Wefer, G., Berger, W.H., Siedler, G., Webb, D.J. (Eds.), The South Atlantic: Present and Past Circulation. Springer, Berlin Heidelberg, pp. 163-210.

Smith, S.V., Hollibaugh, J.T., 1998. Carbon-nitrogen-phosphorus cycling in Tomales Bay, California. Aquatic Geochemistry 4 (3-4), 395-402.

Smith, S.V., Hollibaugh, J.T., Dollar, S.J., Vink, S., 1991. Tomales Bay metabolism- C-N-P stoichiometry and ecosystem heterotrophy at the land sea interface. Estuarine Coastal and Shelf Science 33 (3), 223-257.

Stramma, L., Peterson, R.G., 1989. Geostrophic transport in the Benguela current region. Journal of Physical Oceanography 19, 1440-1448.

Summerhayes, C.P., Kroon, D., Rosell-Mele, A., Jordan, R.W., Schrader, H.-J., Hearn, R., Villanueva, J., Grimalt, J.O., Eglinton, G., 1995. Variability in the Benguela current upwelling system over the past 70,000 years. Progress in Oceanography 35, 207-251.

Takahashi, T., Broecker, W.S., Langer, S., 1985. Redfield ratio based on chemical data from isopycnal surfaces. Journal of Geophysical Research 90 (C4), 6907-6924.

Thamdrup, B., Canfield, D.E., 1996. Pathways of carbon oxidation in continental margin sediments off central Chile. Limnology and Oceanography 41, 1629-1650.

Tyrrell, T., Law, C.S., 1997. Low nitrate: phosphate ratios in the global ocean. Nature 387, 793-796.

Tyrrell, T., Law, C.S., 1998. Low nitrate: phosphate ocean ratios corrected. Nature 393, 318.

Voituriez, B., Herbland, A., 1984. The nitrate temperature relationship in the equatorial upwelling of the Gulf of Guinea. Oceanologica Acta 7, 169-174.

Waldron, H.N., Probyn, T.A., 1992. Nitrate supply and potential new production in the Benguela upwelling system. South African Journal of Marine Science 12, 29-39.

Waldron, H.N., Probyn, T.A., Lutjeharms, J.R.E., Shillington, F.A., 1992. Carbon export associated with the Benguela upwelling system. South African Journal of Marine Science 12, 369-374.

Waldron, H.N., Probyn, T.A., Brundrit, G.B., 1998. Carbon pathways and export associated with the southern Benguela upwelling system: a re-appraisal. South African Journal of Marine Science 19, 113-118. 
Weeks, S.J., Currie, B., Bakun, A., 2002. Satellite imagingmassive emissions of toxic gas in the Atlantic. Nature 415, 493-494.

Wefer, G., Fischer, G., 1993. Seasonal patterns of vertical particle flux in equatorial and coastal upwelling areas of the eastern Atlantic. Deep-Sea Research I 40, 1613-1645.
Woodhead, P., Hamukuaya, H., O’Toole, M.J., Stromme, T., Saetersdal, G., Reiss., M.R., 1997. Catastrophic loss of two billion juvenile hake recruits during widespread anoxia in the Benguela current. In: Recruitment of Exploited Marine Populations: Physical-Biological Interactions. ICES International Symposium, Baltimore, USA, 18pp. 